\title{
THE CORRELATION BETWEEN LEARNING MOTIVATION AND READING COMPREHENSION ACHIEVEMENT AT THE X GRADE STUDENTS OF SMAN 8 BEKASI
}

\author{
Ferawaty Puspitorini ${ }^{1}$, Haris Hamdani ${ }^{2}$ \\ Universitas Bhayangkara Jakarta Raya, Jakarta, Indonesia \\ Universitas Bhayangkara Jakarta Raya, Jakarta, Indonesia \\ fpuspitorin85@gmail.com
}

Submitted: $22 / 08 / 2021$

Accepted: 30/08/2021

Publication: 31/08/2021

\begin{abstract}
This research was conducted to measure whether there is a correlation between learning motivation and reading comprehension achievement. The population of this research is the firstgrade students of SMAN 8 Bekasi that consists of 99 students and was divided into three classes. The total samples are 40 students taken from the entire population by simple random sampling. The method was used in this research is a survey. It means quantitative analysis by using a questionnaire to a lot of objects. In his study, the writer gave questionnaires that consist of forty questions to know their learning motivation. And then, the writer gave multiple-choice tests to know reading comprehension achievement. The result of the calculation of correlation coefficient Phi with 5\% level of significant from the degree of freedom (df) $=\mathrm{N}$ is 3,841 and the interpretation of the score $\chi^{2}$ count and $\chi^{2}$ table indicated that $\chi^{2}$ count $(32,727)>\chi^{2}$ table $(3,841)$. Based on the result above, the null hypothesis $\left(\mathrm{H}_{\mathrm{o}}\right)$ is rejected, and the alternative hypothesis $\left(\mathrm{H}_{\mathrm{a}}\right)$ is accepted. There is a correlation between learning motivation and reading comprehension achievement among the $\mathrm{X}$ grade students of SMAN 8 Bekasi.
\end{abstract}

Keywords - Correlation, Learning Motivation, Reading Comprehension, First Grade, SMAN 8 Bekasi

\section{Introduction}

Reading is one of the language skills noted as a part of important ability in broadening readers' perspectives, giving them a chance to see the world. Reading means understanding the text. In language learning, reading plays a vital role in mastering other language skills. Reading nowadays is not learned apart from other skills, (Fitriana, Nurkamto, \& Pudjobroto, 2015).

In Indonesia, English is a foreign language that begins to be taught from Elementary School, Junior High School, Senior High School, and university. It is obviously that reading ability is one skill that students should acquire. Reading is one of the skills that students of Junior High School should master. Reading without understanding will not mean reading. Many factors influence the success of the task. Those factors come from inside or outside the learner's individual, both related to linguistic and non-linguistic aspects.

It should become the priority in teaching reading of Indonesian. Although teaching English emphasizes teaching reading skills, the English teachers still have trouble making it a success. Some students always read English text word by word or sentence by sentence before they comprehend the text's message. This only makes them fall bored and give up reading.

English is a vital subject necessary for students in senior high school and equivalent to passing the National Exam. Senior high school students are taught reading various kinds of text. Every semester, students learn to read different text types base on the curriculum used that semester. At school, especially Senior High School level, reading comprehension takes most part in English subject. As proof, the teachers give the students reading comprehension rather than 
writing tests, listening tests, or speaking tests in daily tests. They are still hard to get the information of the text or answering the comprehensive questions. It can happen because the student's motivation to read is still low, which impacts their reading comprehension achievement; it can be seen that only a few students can comprehend reading text. This case also happened in the first grade of SMAN 8 Bekasi.

From the explanation above, it can be seen that Indonesia students are not good at reading habits. It is necessary to research students' motivation to learn English, which also affects their marks for English as based on (Sipahutar, 2016), "Motivation has an important role in the teaching-learning process especially in understanding reading comprehension." So it can be assumed that the students with high motivation to learn English will be more successful than those with low inspiration or no reason.

\section{Literature Review \\ Reading Comprehension Achievement}

Reading is one of the four language skills: Listening, Speaking, Reading, and Writing. Reading is one of the abilities that I have to reach my students in the English learning process. (Dewi, Fahrurrozi, Hasanah, \& Wahyudi, 2020), "Reading comprehension is an activity to find meaning or message from the writer through the text they read. Reading comprehension is also an essential language skill that supports the development of other language skills. Having good reading English skills is very important for the students. It can help the students enlarge their knowledge because they can get a lot of information through reading (Dartini, 2009).

(Sipahutar, 2016) also explained that reading is an essential aspect of the learning process. With reading, the students can get more information to enrich their knowledge in understanding English. The students will also make more excellent progress and attain more significant development in academic areas such as understanding English with reading skills.

Reading comprehension is a complex interaction among automatic and strategic cognitive processes that enables the reader to create a mental representation of the text, (Sartika, Afifah, \& Anggraini, 2020). They also mentioned that there are three different level of comprehension, they are; literal level, interpretive level, and applied level.

The first is the literal level the message is clearly stated in the text, the second is the interpretive level the reader are attempting to understand what is implied or meant, breather what is actually stated, and the last is the applied level reader take what was said (literal) and what was meant by what was said (interpretive) and then extended (use) the concept or ideas beyond the situation. It means that there are three levels of comprehension to know the students' understanding, such as type of test comprehension.

Based on the experts' opinion above, it can be concluded that students should be taught to read first to know and understand unknown elements, whether these are ideas or simple ideas. Then, they must be taught to read to find out the details in reading more deeply. Therefore reading techniques such as reading speed is the thing that needs to be taught to them.

\section{Learning Motivation}

Motivation cannot be touched but can feel and long-term influence on people. (Dörnyei \& Ushioda, 2013) quoted that motivation is responsible for why people decide to do something, how long they are willing to sustain the activity, and how hard they will pursue it". It means that motivation is an activity to do something how long and hard the activity to follow it.

(Mihandoost, Elias, Sharifah, \& Mahmud, 2011) States that motivation for reading is a crucial entity for successfully engaging in the reading process because it is the element that activates and maintains students' engagement throughout the entire reading process. To increase reading comprehension, we must be active readers; we can get pointless exercise, frustration and not have more knowledge without an active reader.

Learning motivation is easy once you know how to do it. Reason has to come from inside. It's natural to be influenced by other people, but that motivation must come from you if 
you want to accomplish your goals.

Set realistic goals and imagine yourself accomplishing them. Visualization can be a powerful tool in learning motivation. When you go through in your mind what it feels like to accomplish something, your mind already knows what to expect, and you are more likely to fulfill your expectations.

Motivation is divided into two; they are extrinsic \& intrinsic motivation, based on (Marsela, 2017). Inline to ("Student Motivation - An Overlooked Piece of," n.d.), intrinsic motivation is the desire to do or achieve something because one genuinely wants to and takes pleasure or sees value in doing so. For definition above, inherent motivation is from inside an individual rather than for doing well something. At the same time, extrinsic motivation is the answer to help the students to feel more confident in answering mathematics examinations or quizzes. It means that extrinsic motivation can make self-confidence to help students to answer doing something difficult.

(Studi \& Bahasa, 2013) supported that reading motivation is broadly divided into two kinds of reading motivation: intrinsic and extrinsic. Intrinsic motivation is the motivation that comes from oneself, while extrinsic motivation is a motivation that comes from outside. Reading motivation is essential to improve students achievement in academic; students' achievement in academics can be high and low depends on their motivation in reading.

Based on the definitions above, it can be concluded that learning motivation is changing the energy in somebody that is marked with the appearance of feeling and proceeded by the response. Learning motivation also includes 1). Immediate achievement, learning the target language to obtain satisfactory results of the score; 2). Learning situation, learning English because of aspects of the learning environment such as the quality of teaching, teaching materials, teachers, and affiliation with the learning group; 3). Individual development, learning English to increase one's ability and social status in future growth, could be as general as acquiring "a sense of achievement"; and 4). Information medium, learning English to obtain information and learn other subjects.

\section{Research Method}

This research focused on the correlation between learning motivation and Reading comprehension achievement.

The data was taken from both variables; they are independent variables with a questionnaire to the students. It was done to measure their learning motivation and dependent variable with a Multiple Choice test Text to measure their reading Comprehension for students class X SMAN 8 Bekasi.

The participants of this research were the first-grade students of SMAN 8 Bekasi that consists of 99 students and is divided into three classes. The total samples are 40 students taken from the entire population by simple random sampling.

\section{Results and Discussions}

Before doing Hypothesis Examination statistically tests conditions of normality distribution of population to each variable by using statistic test the Kolmogorov-Smirnov by using program SPSS. The result presented in table: 
Table 4.2

Test of normality

\begin{tabular}{|c|l|c|c|c|c|}
\hline No & \multicolumn{1}{|c|}{ Variables } & $\begin{array}{c}\text { KS }-\mathbf{Z} \\
\text { D count }\end{array}$ & D table & Asym-sig & Note \\
\hline 1. & Learning Motivation & 0,582 & 0,2150 & 0,007 & $\mathrm{H}_{0}$ is rejected \\
\hline 2. & $\begin{array}{l}\text { Reading Comprehension } \\
\text { Achievement }\end{array}$ & 0,897 & 0,2150 & 0,009 & $\mathrm{H}_{\mathrm{a}}$ is accepted \\
\hline
\end{tabular}

Because assumption of normality for two variables is not fulfilled (Ho is rejected) and fulfilled (Ha is accepted). So, Pearson correlation coefficient cannot be applied at process of the research data analysis and as alternatively using by correlation coefficient Phi.

For this research we can divide into two classifications for the research variable, there are:

1. Learning motivation score shows that category aspect divided into Low and high.

2. Reading comprehension score shows that category aspect divided into Bad and Good.

To transform the data score from numeric variable that is got from test for learning motivation and reading comprehension achievement to category aspects two classification is based on the numeric scores of two variables to the scores itself through the requirement as follow:

a. If learning motivation score of test are:

1. Smaller $(<)$ than mean $=76,38$. So, it will be entered into low classification

2. Bigger $(\geq)$ than mean $=76,38$. So, it would be entered into high classification

b. If reading comprehension achievement score of test are:

1. Smaller $(<)$ than mean $=77,20$. So, it would be entered into bad classification

2. Bigger $(\geq)$ than mean $=77,20$. So, it would be entered into good classification.

By using score Mean that was conducted by transformation from data, the score of result of test is in the form of numeric become the category. It was as operational definition together with the classifications categorize. Variable $\mathrm{X}$ became low and high and Variable $\mathrm{Y}$ became good and bad. his result is presented in tables 4.3:

\section{Tabel 43 \\ learning motivation * reading compre.achievement \\ Crosstabulation}

\begin{tabular}{|c|c|c|c|c|}
\hline \multicolumn{3}{|c|}{ reading } & vement & \multirow[b]{2}{*}{ Total } \\
\hline & & $\mathrm{Bad}$ & Good & \\
\hline \multirow{2}{*}{ learning motivation } & Low & 20 & & 20 \\
\hline & High & 2 & 18 & 20 \\
\hline Total & & 22 & 18 & 40 \\
\hline
\end{tabular}

Before conducting the process of hypothesis examination is beforehand determined by value of correlation coefficient of phi by using SPSS (Statistical Package for Service Solution). Pursuant to calculation the result obtained by value of correlation coefficient phi $(\mathrm{r} / \mathrm{phi}=0$, 905). Measures this Correlation is inclusive of strong category with the direct pattern.

By choosing real significant $=0,05$ and degree of freedom $(\mathrm{df})=1$, so the score of Chi Square $\chi^{2}$ table $=3,841$. While $\chi^{2}$ count based on the SPSS (Statistical Package for Service 
Solution) is 32, 727. Then, the comparison result of both scores are $\chi^{2}$ count $=32,727(>) \chi^{2}$ table $=3,841$. So the test of hypothesis shows that Ho is rejected and Ha is accepted. Its can be seen on the table below:

Table 4.4

The result of Hypothesis Test

\begin{tabular}{|c|c|c|l|}
\hline $\mathbf{r}_{\text {count }}$ & $\chi^{2}$ count & $\chi^{2}$ table & \multicolumn{1}{|c|}{ Note } \\
\hline 0,905 & 32,727 & 3,841 & $\begin{array}{l}\mathrm{H}_{0} \text { is rejected } \\
\mathrm{H}_{\mathrm{a}} \text { is accepted }\end{array}$ \\
\hline
\end{tabular}

\section{Conclusion}

Based on the findings above, they can be concluded as follows: (1) The coefficient correlation score have strong related between learning motivation and reading comprehension achievement is 0,905 ; (2) Both on the research variables has the direct pattern and has correlate of solid category, and (3) The correlation degree between learning motivation and reading comprehension achievement can describe the relation pattern is overall of the population at grade $\mathrm{X}$ as the target population including at population target of SMAN 8 Bekasi.

\section{References}

Dartini, D. (2009). Improving Students' Reading Comprehension of Narrative Texts By Using Small Group Discussions At the Grade X a Ma Kmi of Diniyyah Puteri Padang Panjang. Lingua Didaktika: Jurnal Bahasa Dan Pembelajaran Bahasa, 3(1), 13. https://doi.org/10.24036/ld.v3i1.7366

Dewi, R. S., Fahrurrozi, Hasanah, U., \& Wahyudi, A. (2020). Reading Interest And Reading Comprehension A Correlational Study in Syarif Hidayatullah State Islamic University, Jakarta. Talent Development \& Excellence, 12(1), 241-250. Retrieved from http://search.ebscohost.com/login.aspx?direct=true \&db=s3h\&AN=144307159\&login.asp \&lang $=$ es\&site $=$ ehost-live

Dörnyei, Z., \& Ushioda, E. (2013). Teaching and researching motivation, second edition. Teaching and Researching Motivation, Second Edition. https://doi.org/10.4324/9781315833750

Fitriana, F. N., Nurkamto, J., \& Pudjobroto, A. H. (2015). A correlation between learning motivation and vocabulary mastery and reading competence, $1-17$.

Marsela, S. (2017). THE CORRELATION BETWEEN READING MOTIVATION AND READING COMPREHENSION ACHIEVEMENT OF THE ELEVENTH GRADE STUDENTS OF MAN 2 PALEMBANG This thesis was accpeted as one of the requirement to get the title of sarjana pendidikan ( S , Pd .) by Seli Marsela ENGLIS, 2021.

Mihandoost, Z., Elias, H., Sharifah, P., \& Mahmud, R. (2011). A Comparison of the Reading Motivation and Reading Attitude of Students with Dyslexia and Students without Dyslexia in the Elementary Schools in Ilam, Iran. International Journal of Psychological Studies, 3(1), 17-27. https://doi.org/10.5539/ijps.v3n1p17

Sartika, F. D., Afifah, N., \& Anggraini, Y. (2020). the Correlation Between Students' Reading Habit and Their Reading Comprehension. Jurnal Basis, 7(1), 207. https://doi.org/10.33884/basisupb.v7i1.1856

Sipahutar, I. S. M. \& R. A. (2016). The Correlation between Motivation and Students' Achievement in Reading Comprehension at SMP Negeri 8 Grade VIII Pematangsiantar. Journal of English Teaching as a Foreign Language, 2(1), 29.

Student Motivation - An Overlooked Piece of. (n.d.), 1-12.

Studi, P., \& Bahasa, P. (2013). the Correlation Between Reading Comprehension, (March). 
IJEAL (International Journal of English and Applied Linguistics)

Volume : 1 | Number 2 | August 2021 | E-ISSN : 2787-9482 |DOI: doi.org/ijeal.v1n1.1063 